\title{
UNIVERSITY RANKINGS: THE MANY SIDES OF THE DEBATE
}

\author{
Mmantsetsa, MAROPE ${ }^{1}$, Peter J., WELLS ${ }^{2}$ and Silvia, FLOREA ${ }^{3}$ \\ ${ }^{1}$ UNESCO, France, email: m.marope@unesco.org \\ ${ }^{2}$ Bucharest Professional Training College, Romania, email: peter.wells@bptc.ro \\ 3”Lucian Blaga" University of Sibiu, Romania, email: silvia.florea@ulbsibiu.ro
}

\begin{abstract}
Within the context of bourgeoning institutions that rank higher education institutions, this paper examines the merits and demerits of university rankings and diverse ranking methodologies. It explores and presents recent developments and diversification of international rankings and highlights their general trend towards more broadly balanced and multidimensional criteria. The paper concludes that like any other complex endeavour, rankings have their pros and cons but the latter does not justify their abandonment. What is required is public education that builds a discerning user who can optimally gain from the use of rankings while avoiding their pitfalls. The original version of this article was first published in the UNESCO volume Rankings and Accountability in Higher Education: Uses and Misuses (2013) Paris: UNESCO.
\end{abstract}

KEY WORDS: ranking, university, sustainability, quality, world-class

\section{INTRODUCTION}

The practice of university rankings dates back to around 1900 with the publication in England of Where We Get Our Best Men. Based on the backgrounds of the country's most prominent scientists, this study provided for the first time a list of universities ranked by the number of distinguished alumni they could lay claim to (Myers and Robe, 2009). With the publication of 'America's Best Colleges' by the US News and World Report (1983) and a decade later, of the 'Times Good University Guide' (1993) in the UK, the tide of attention paid to university rankings considerably changed, culminating in 2003 with the release of the Academic Ranking of World Universities (ARWU) by Shanghai Jiao Tong University in China and the Times Higher Education World University Rankings (2004). The topic has rarely been out of higher education headlines and mainstream media ever since and has progressively attracted ever more pro as well as anti-ranking debates, initiatives and, of late, ranking methodologies and bodies.

The explosion of university rankings is indicative of the highly compared, ranked world we live in and of the complexity of its assessment dimensions. With universities being canonical institutions, it has become increasingly difficult to provide comprehensive and balanced comparisons and hence to assess not only global university performance across universities' core missions, but also generally accepted, calibrated performance indicators. The use of common 'yardsticks' to measure universities in terms of their very complex, often multi-faceted, fast-changing, contextually varied and even conceptually contentious indicators has triggered considerable public debate. It also seems to be triggering the emergence of various ranking methodologies seemingly created to only make up for the appearance of more, better and more-inclusive ranking lists. This would be posing no real problem in itself, were such comparisons and rankings not to substantially influence both individual and collective decisions. In the case of universities, this influence of comparisons and rankings goes well beyond the individual's own choices to collective choices about the country's policy, its strategic and investment priorities, the country's strategic positioning and competitiveness of its higher education institutions. As the proand anti-ranking debate rages on, the question seems to be less about whether or not universities should be compared and ranked, but more about the manner in which such comparison is to be undertaken.

Oversimplifying the complex quality and dynamics of higher education institutions has been a consistent criticism of university rankings. If we examine the methodological approaches used by three of the most prominent 'ranking houses' that vary in their construct and rationale, we notice that the indicators they use are explicitly selective and not exhaustive. Furthermore, ranking houses overtly recognize that no matter how much they may expand the base of indicators considered in their methodologies, they can never exhaustively cover the full range of the universities' functions and activities. As such, they responsibly caution that, none of the current global ranking systems can provide a complete view of universities; as such, taking any single ranking as a standard to judge a university's overall performance is improper (Liu, 2012). More to the point, the ranking houses acknowledge the limited coverage of their 'world university rankings', as they focus on only about 200 (or 1 per cent) of the nearly 17,000 world universities. Although varied in many respects, the 200 ranked universities have much in common. According to Baty (2012), they publish 'world-class' research carried out across national borders, work with global industry, teach from undergraduate to doctoral level and compete in a global market for the top students and academic talent. However, for all these similarities, the scope of the currently main rankings remains still limited: "different global rankings have different purposes and they only measure parts of universities' activities. Bibliometric rankings focus on research output, and URWU emphasizes the research dimension of universities also" (Liu, 2012). 
Another important aspect is that hitherto, rankings have embraced only 1 per cent of the world's universities, and even then, they focused mainly on research, mostly scientific research. This narrow focus has been criticized for ignoring the full scope of the core functions of universities-teaching, research and social responsibility. Against mounting criticism for this narrow focus, major 'ranking houses' are progressively responding by broadening their criteria. For instance,

the new Times Higher Education World University Rankings, first published on 16 September 2010 and again on 6 October 2011 recognize a wider range of what global universities do ... the The World University Rankings seek to capture the full range of a global university's activities - research, teaching, knowledge transfer and internationalisation.... Perhaps the most dramatic innovation for the world university rankings for 2010 and beyond is the set of five indicators designed to give proper credit to the role of teaching in universities with a collective weighting of 30 per cent. (Baty, 2012)

While such methodological improvements speak well of the ranking houses as learning institutions, critics point to this methodological evolution as a source of longitudinal incomparability of rankings and, therefore, a weakness in itself. Yet, for the rankings user, the fact that more or less the same universities appear more or less in the same ranked position suggests a fair measure of stability even as methodologies evolve. Beyond methodological improvements, criticism of rankings is strengthening the call for other mechanisms for monitoring and strengthening the quality of higher education accreditation.

We need current accreditation to do what it does well, which is to encourage sustaining innovation and monitor traditional quality metrics. We also badly need an alternative system that encourages new higher education business models that do such things as better serve new classes of customers, radically attack the high cost structure of higher education, and increase student learning, while providing new oversight mechanisms appropriate to such models. The same organization cannot play both roles. (Armstrong, 2013)

At the same time, accreditation is itself not without criticism. Indeed, there seem to be additional constraints related to how accreditation is actually designed to measure (and improve) the actual delivered excellence promised in the institutional value propositions. Unfortunately,

Higher education has very little ability (or desire?) to measure meaningful actual outcomes. As a consequence, accreditation has traditionally focused on elements of resources and procedures - number and academic profile of faculty, dollars spent per student, hours of seat time to degree, etc. Thus, accreditation is only possible for institutions that provide resources and operate with procedures that fall within the traditional understanding of what is required to produce traditionally defined excellence. (Armstrong, 2013)

Without a doubt, the explosion of interest in rankings has been outmatched by the volume of criticism from virtually all spheres, including academics, universities, policy-makers, development agencies, education service providers and students. However, on the positive side, rankings do address the growing demand for accessible, manageably packaged and relatively simple information on the 'quality of higher education institutions'. This is particularly significant, given the growing stakeholder's need to make informed choices of universities, within a context of widely growing diversity of providers. Rankings 'have also led to a revolution in the availability of data on higher education institutions and intelligence to guide institutional and government strategies for higher education' (Sowter, 2012). Indeed, the 'pull-up factor' has been notably working on universities that appear to be lacking in some of the criteria used for rankings and are striving to move higher on the list, concomitantly with the ever more powerful incentive for sustaining quality enhancement forces that has been fuelling the universities that 'do well' in rankings. Rankings can and have been therefore indirect tools for driving excellence in higher education (Hapsah, 2012).

Other than the narrow scope of coverage of university functions, there has been growing concern about the potential perverse impact of the 'pull up factor' leading to the 'McDonaldization' of higher education institutions as they all try to mimic the 200 best-ranked institutions. Kevin Downing (2012) allays these concerns, and points out that HEIs are mature, sophisticated and complex enough to balance the responsiveness to globalization imperatives with those of the demands of their immediate contexts.

There has equally been concern that the "good scorers", tend to be older (200+years) established institutions with 25,000 students or more, 2,500 faculty or more, and with endowments of over US\$1 billion and annual budgets of more than US\$2 billion. Rankings are seen as favouring these 'touchstone' institutions and do not accord due credit to those which represent higher value added. However, this represents a departure from the self-declared focus of rankings, which emphasizes quality at the pinnacle and not (so much) the process of getting there.

Granted, unwise use of rankings is a source of equally great concern, but the remedy to this challenge is public education of users and certainly not the elimination of rankings. The Malaysian experience with rankings demonstrates how, with progressive understanding of the merits and demerits of rankings, countries and by implication, regions, can adapt rankings to make them responsive to their contexts:

As the issues surrounding rankings became clearer the government has taken a more holistic view about ranking. The Minister of Higher Education has expressly articulated that universities should not be 'obsessed with ranking' (as qtd in Khaled Nordin, 2011) [...] Instead the government is focusing more on making the education system 'world class' to accommodate the increasing entrants to higher education. Under the Economic Transformation Programme (PEMANDU), several initiatives have been identified for improving the supply as well as demand side to increase access and enhance quality towards making Malaysia a global education hub. Consequently in implementing the Ninth Plan, the selection of research universities was completed. (Hapsah, 2012)

A further criticism of rankings is that they divert resources from building 'world-class' higher education systems towards building 'world-class' higher education institutions. This is yet another issue of usage rather than of rankings per se. It is quite difficult to envisage the possibility of having 'world-class' higher education systems without 'world-class' higher education institutions. The artificial partitioning of the two asks 
the right question for the wrong reasons. The right question regarding how best we can have a 'world-class' higher education system absolutely has to be asked. It is a question with a powerful equity imperative that recognizes that all deserve quality higher education. But the wrong reason that rankings should be abolished because they encourage the building of world-class universities and not world-class higher education institutions simply separates the chicken from the egg. A critical, legitimate question that critics should ask is: How can countries attain and sustain world-class universities and higher education systems and do so with sustainable resource efficiency?

Equally important, since performance in rankings can have an impact on ability to generate funding and partnerships, there is a "perverse" incentive for universities to inflate their performance in order to climb up the ladder, which represents a legitimate concern with any such high-stakes assessment mechanism. However, verifying the validity of information that universities provide to 'ranking houses' remains a challenge and has to follow certain procedural steps in the process of performance assessment.

In an effort to address the above-outlined weaknesses, several complementary methodologies and ranking bodies have lately emerged so as to include more group and individual characteristics of institutions they seek to compare. Such is the ambitious OECD attempt to draw international comparisons of the learning outcomes of higher education graduates, a dimension that addresses the personal and social fulfilment of students after graduation. Similarly, the World Bank proposes to complement rankings with a benchmarking approach intended to run a 'health check' on tertiary education systems around the world. The ultimate purpose is, certainly, not to create a list of winners and losers, but to offer a way for national higher education systems to develop further strategies for improvements. A possible danger posed by such a holistictherapy approach may be represented by the risk of bypassing fundamental shortcomings at the institutional level that need to be addressed and resolved if the/any system is to function efficiently. Along other 'multi-dimensionality' lines, the UMultirank project ensures an additional tool that allows for a broader analysis of the diversity of tertiary institutions. Encapsulating the perspective that modern higher education institutions are 'predominantly multi-purpose, multiple-mission organisations, undertaking different mixes of activities (teaching and learning, research, knowledge exchange, regional engagement, and internationalisation' (van Vught and Ziegele, 2012), the U-Multirank project represents another such welcome addition to the institutional comparison toolkit.

All these complementary approaches have stemmed from the desire to perfect a system that seems to be still vulnerable in many aspects; indeed, 'no one size fits all', and comparison should be based on similarities in systems, as one incorporating diverse approaches to the assessment of higher education inputs, processes, and outputs. Rankings are designed to provide comparative information and improved understanding of higher education indicators, but they should equally acknowledge the diversity of institutions, and in so doing, consider different missions and goals of HEIs. In this respect, quality measures for research-oriented institutions are a lot different from those for institutions whose mission is to provide broad(er) access to underserved student populations. Likewise, not all nations or systems share the same values and/or understanding of what "quality" represents in tertiary institutions therefore, ranking systems should not be devised to push such comparisons.

There is yet another side to the problem; these complementary approaches represent gateways for HEIs to be included in rankings in which they had not been previously and most of which are apt to reflect the shifts (and equally the importance) of ranking variables and national indicators. Such is the case of Romanian universities, for example, absent in the Shanghai Ranking, but present in the QS World University Rankings ${ }^{\circledR}$, an IREG approved compiler of global and regional university rankings. While the 2012 QS University Ranking listed four Romanian universities occupying positions between 600 and 700 ("Alexandru Ioan Cuza" University of Iaşi, Babeş-Bolyai University of Cluj-Napoca, the University of Bucharest, and the University of the West of Timişoara), the 2013 QS World University Ranking lists the same four universities occupying positions between 700 and 800, having fallen 100 positions within only one year (HotNews.ro, 2013). Ben Sowter, Head of the Research Unit of QS, quotes the economic situation, difficulties of the $\mathrm{HE}$ system, number of citations and decreasing number of international students and teaching staff, as major causes for the low position acquired in the 2013 standing. What is important here, is that the position in the international ranking is reflected in and confirmed by the national university ranking (http://www.edu.ro/), the first three universities having been ranked as the first three HEIs in the first category, that of education and research advanced universities, whereas the University of the West of Timişoara occupies the first position in the second category, that of education and research universities.

By way of conclusion, there is now an increasingly clearer convergence of opinion on what ranking tables and methodologies can and cannot tell from both the users and compilers of university rankings. Ultimately, it matters little whether a stated comparative objective is to 'rank', 'list', 'score', 'benchmark' or 'map'. If such initiatives, regardless of their results or the controversies they provoke, will raise the profile and importance of addressing the need for quality monitoring and quality enhancement in higher education, then they have reached their ultimate and worthy goal(s).

Those 15,000+ institutions around the world that have not, do not and will not appear on any 'top' list of universities will continue their noble pursuits of educating and nurturing their students, hungry for knowledge and skills and will continue to bring their contribution to the development of human and social capital. In her opening address to the 'Global Forum on Rankings', the Director-General of UNESCO offered a timely reminder of the values and missions of higher education.

University rankings are a hotly debated issue. They are viewed in very different ways by rankers, students, employers, pre-university level schools and the higher education community. It is good to see that international rankings are diversifying and moving towards more broadly balanced criteria and becoming multidimensional, as are national rankings [...]. While competition and international comparisons can be positive trends, a key challenge for us in UNESCO is to continue promoting the values of higher education and the three main missions of the university: research, teaching and community service. (Address by Irina Bokova, UNESCO, 16 May 2011)

Overall, discerning stakeholders subscribe to the use of rankings in complementarity with other credible sources of 
information on the quality of a university, including quality enhancement efforts, evidence of value addition to learners, quality assurance and universities' evidence-based selfreporting on their quality. In this context, the next ten years will hopefully mark the maturing of university rankings, and further define a period of improved responsibility in the creation, dissemination and application of higher education rankings.

\section{REFERENCES}

1. Academic Ranking of World Universities - 2012 www.arwu.org/

2. America's Best Colleges, US News and World Report, Available at:

http://colleges.usnews.rankingsandreviews.com/bestcolleges. (Accessed 1 November, 2012).

3. Armstrong, Lloyd, "Accreditation: ally or obstacle as higher education wrestles with change?", available at: http://www.changinghighereducation.com/2013/10/accredi tation-ally-or-obstacle-as-higher-education-wrestles-withchange-.html\#more

4. Baty, P. (2012), "An Evolving Methodology: the Times Higher Education World University Rankings", in Rankings and Accountability in Higher Education: Uses and Misuses (pp. 41-53) Paris: UNESCO.

5. Bokova, Irina, UNESCO Address, May 16, 2011, available at:

http://unesdoc.unesco.org/images/0019/001924/192417m. pdf

6. Downing, K. (2012), "What's the Use of Rankings?", in Rankings and Accountability in Higher Education: Uses and Misuses (pp. 197-208) Paris: UNESCO.

7. Hapsah, S. (2012), "The National and Institutional Impact of University Rankings: the case of Malaysia", in Rankings and Accountability in Higher Education: Uses and Misuses (pp. 187-196) Paris: UNESCO.

8. HotNews.ro 2013, available at: http:/www.hotnews.ro/stiri-esential-15550614clasamentul-international-universitatilor-2013-patruuniversitati-din-romania-sunt-incluse-top-800-mondialcadere-100-pozitii-fata-anul-trecut.htm

9. Liu, N. C. (2012), "The Academic-Ranking of Word Universities and its Future Direction", in Rankings and Accountability in Higher Education: Uses and Misuses (pp. 23-40) Paris: UNESCO.

10. Maclean, A. H. H. (1900), "Where we get our best Men. Some statistics showing their nationalities, counties, towns, schools, universities, and other antecedents: 18371897', London.

11. Ministerul Educatiei Nationale: http://www.edu.ro/index.php/articles/15647

12. Myers, L. and Robe, J. (2009). Report from the Center for College Affordability and Productivity: www.centerforcollegeaffordability.org/uploads/College_R ankings_History.pdf (Accessed 20 August 2012.)

13. Sowter, B. (2012), "Issues of Transparency and Applicability in Global University Rankings", in Rankings and Accountability in Higher Education: Uses and Misuses (pp. 55-68) Paris: UNESCO

14. Van Vught, F. and Ziegel, F. (2012), "U-Multirank: a userdriven and multi-dimensional ranking tool in global higher education and Research", in Rankings and Accountability in Higher Education: Uses and Misuses (pp. 257-280) Paris: UNESCO.

15. "Times Higher Education World University Rankings 2011-12", Available at: www.timeshighereducation.co.uk/world-universityrankings/

16. UNESCO Global Forum: Rankings and Accountability in Higher Education: Uses and Misuses, Paris, 16-17 May 2011:

17. http://www.unesco.org/new/en/education/themes/strengthe ning-education-systems/higher-education/qualityassurance/rankings-forum/ (Accessed 2 July 2013) 